Proceedings of the 1st international conference Economic and Business Trends Shaping the Future $\mid 2020$

\title{
STUDENT'S PERCEPTIONS ON BENEFITS AND CHALLENGES OF USING GOOGLE CLOUD-BASED TOOLS FOR E-LEARNING
}

\author{
Dejan Zdraveski, PhD \\ Faculty of Economics - Prilep, St Kliment Ohridski University \\ dejan.zdraveski@uklo.edu.mk \\ Margarita Janeska, PhD \\ Faculty of Economics - Prilep, St Kliment Ohridski University \\ mjaneska@yahoo.com \\ Kosta Sotiroski, PhD \\ Faculty of Economics - Prilep, St Kliment Ohridski University \\ kostasotiroski@gmail.com \\ Gjorgji Manceski, PhD \\ Faculty of Economics - Prilep, St Kliment Ohridski University \\ gmanceski@t-home.mk
}

\begin{abstract}
The introduction of innovations in traditional education systems has imposed the need for adjustments and changes to the entire education system and its participants. The most important moment in the evolution of educational systems is the emergence of e-learning platforms as a result of the growing importance of lifelong learning and their integration into traditional educational environments. Especially nowadays, when the world is facing with the pandemic of Covid 19, the importance of the e-learning process and the use of distance learning platforms comes to the fore. The Faculty of Economics in Prilep is adapting to the new situation. For the realization of the process of distance learning were used the tools of Google, i.e. the G Suite cloud-based tools, such as Google Meet, Google Classroom, Gmail, Google Sheets, Google Docs, Google Drive etc.

In this paper we will explore the perceptions of students at the Faculty of Economics in Prilep in terms of the benefits provided by these tools and the challenges faced by students in such a new situation where teaching took place completely on-line. For that purpose, a survey was conducted in which students from all study years were included. In this paper will be presented a qualitative and quantitative analysis of the obtained answers through the survey. The questionnaire was created with Google Forms and was delivered to students through the e mail.

The main aim of this paper is to detect student's perceptions of the use of cloud-based elearning tools. In the future, when creating and accrediting study programs, the recommendations contained in this paper could be taken into account in order to introduce elearning as a one of the possible ways for realization of educational process.
\end{abstract}

Key words: education, e-learning, cloud computing, innovation

JEL classification: I23, D83, C88

http://doi.org/10.47063/EBTSF.2020.0024

http://hdl.handle.net/20.500.12188/9710 


\section{INTRODUCTION}

Education is a key strategic element in enabling sustainable economic growth in the country. A country's education system must actively respond to external challenges, demonstrating strong flexibility and openness to innovation. Now more than ever, the focus is on the student, his requirements and expectations, as a follow-up to his individual capabilities and capacities. On the other hand, the intensive development of information technologies means their inevitable use in all aspects of social life, as well as in the educational system of a country (Zivanovic R. and all., 2010). The inclusion of information technology in the teaching and learning process is important component in all areas of higher education (Usun S, (2005). These technologies do not define society only in terms of access to information, but dictate its transformation into a knowledge society. Such a transformation of society is achieved if an effective change of the education system is enabled and new concepts of education are introduced. In that context, information technology is not only a means for achieving educational goals but also an important factor in restructuring the education system (Means and Olson, 1995).

Higher education as one of the foundations of society encourages and supports the development of the information society, i.e. higher education should be a promoter of the information society. This means creating professionals who will be able to respond to the challenges and needs in all segments of society. Following the development of information and communication technologies, higher education means creating young and innovative peoples who would deal with the challenges. One of the answers to this need is the development of e-learning. This new way of teaching and delivering of information to students have a growing expansion in the world, but also in Republic of North Macedonia. Also, the new reality that imposed the pandemic of the Covid 19 virus put e-learning in the foreground as a new way of implementing study programs at all universities in the world (Wahab A., 2020). The universities in the Republic of North Macedonia had to adapt to such a new reality by applying appropriate distance learning tools for the realization of the curricula.

E-learning as a teaching medium differs significantly from direct (face-to-face) delivery of information and knowledge and requires new options for courses development, their evaluation and interaction. The transition to online learning in large scale is very difficult because it is very complex even in the best of circumstances (World Bank, 2020). Software packages designed to help professors to create quality online courses have the role of facilitators of communication between teachers in the role of mentors and coordinators and its students.

\section{CONCEPTUAL FRAMEWROK OF E-LEARNING PROCESS}

E-learning is a computer based educational tool or system that enables to learn anywhere and at any time and is mostly delivered through the Internet. Technology has advanced so much that the geographical gap is bridged with the use of tools that make you feel as if you are inside the classroom. E-learning offers the ability to share material in all kinds of formats and communication between participants of the process without barriers.

The term e-Learning dates back to the 1990s, when various applications began to take on a recognizable form. The first type of definition includes the following: "E-learning refers to the use of computer and network technology to acquire knowledge and skills" (Kenneth J. and Brown A. (2005). By the early 90s several schools had been set up that delivered courses online only and bringing education to people who wouldn't previously have been able to attend a college due to geographical or time constraints. Technological advancements also helped educational establishments reduce the costs of distance learning, a saving that would also be passed on to the students - helping bring education to a wider audience. 
E-Learning, in comparison with traditional learning, significantly reduces the time needed to locate information. It also offers access to online resources, databases, periodicals, journals and other material that students wouldn't normally have access to from a library. If a student has trouble understanding part of the coursework, finding tips on the matter couldn't be easier than having immediate access to supplementary, unlimited and mostly free material online. Those characteristics can potentially maximize the time spent actually learning rather than looking for information. Universities already embrace the power of e-learning to deliver content to students all over the world, even for free. At a time in which universities are under great pressure to deliver education, combining technology with education is integral to coming up with a final product that will empower the educational institution, set it apart, and allow it to grow its student base worldwide.

The European Commission proposes a broad definition of e-learning: "using new multimedia technologies and the Internet to improve the quality of learning by providing access to resources and services, as well as distance exchange and collaboration" (quoted in Nerguizian V. and all., 2011).

In many organizations and institutions, e-learning has been completely adopted as part of the training strategy. The Internet and its related technologies have enabled the integration of many different learning resources and a wide range of ways, activities, and modules through which learning can be implemented. The most important activities and modules through which the e-learning process goes are Lectures (instructions, concept, demonstration, workshops), Collaboration, Practice (software simulations, interactive exercises, problem analysis, web projects, online laboratories) and Evaluation.

E-learning is a technology-supported type of education (Technology supported education / learning) where the medium of teaching is through computer technology, especially with the inclusion of digital technologies. Very often e-learning is called "pedagogy empowered by digital technology" (Titrade C. and all., 2009).

Today there are a number of e-learning systems and platforms. Some of them are open source, others have a protected source code and are made for commercial purposes, and also there are cloud computing platforms for e-learning. Some of them are free to use, some have minimal usage fee, and some are relatively expensive, and include maintenance, servicing and updates. Differentiation also can be made according to whether they are in one or more languages, especially because of the international dimension of the larger companies and institutions that apply them. To be used effectively, the selected e-learning platforms need an overall evaluation of the utility and usability specifications to be well exploited and used in the best conditions (Ouadoud M., 2016).

\section{BASIC TOOLS OF G SUITE FOR EDUCATION}

Perhaps the most well-known and commonly used e-learning tools for education are Google's distance learning tools. Those tools are united in a cloud e-learning platform called G Suite for Education (Google Apps for Education). To use this platform, educational institutions had to create a Google account as an institution that implies certain administrative responsibilities such as creating accounts for all users who are part of the institution (professors, administration and students). The University of St. Kliment Ohridski and thus the Faculty of Economics in Prilep meets this basic prerequisite for using G Suite for Education. This cloud platform was used also previously for distance learning but mostly in second and third cycle of studies. Especially during the pandemic with the Covid 19 virus, G Suite for Education was used for the realization of the teaching process through e-learning on all cycle of studies and on full capacity.

It is a cloud platform that has applications that are fully compatible with each other. This platform allows user-friendly oriented communication between students and professors and 
enable performs a number of tasks that are specific for modern teaching and learning process. It's very useful that any of these applications is customizable by the client. The most often used cloud-based tools from $\mathrm{G}$ Suit for education platform are:

- G-mail- G-mail is a common e-mail tool that provides a simple way to create an account for each user. Each user has a 25 GB of storage space which is directly connected and provided by the data storage tool Google Drive. Google's e-mail tool also has an effective anti-spam filter. Each account can be customized depending on the user's needs.

- Google Classroom- Google classroom is platform on which teacher can organize material and assignment for students. All class materials can be stored on Google drive. This feature helps teachers to see weather student complete the work and give real time feedback and grade. In addition to providing communication between professors and students, this platform also provides communication between the students themselves. Teachers can grade assignments and return them to the students with feedback.

- Google Hangouts and meet- Google Hangout gives users the opportunity to hold virtual meetings, virtual training classes, remote interviews and many other benefits. It is directly related to Google Calendar, where meetings, trainings and interviews are scheduled. This tool allows mutual communication of a maximum of 250 participants.

- Google Drive- Google drive can be used for storing photos, videos, document files and folders. Google drive is a cloud storage platform and users can access to the resources through any devices, any time from any place. Also, these resources that are stored on Google Drive can be shared with some group or individuals. Very useful is possibility that offers to users to work on same files simultaneously. This feature allows to user collaboration and communication.

- Google Calendar- Time-management and scheduling calendar service that allows users to keep track of all their events and tasks. These tasks can be either shared with selective users or kept public for the class to subscribe.

- Google Forms- Google forms as a tool can be used for different needs of teachers. This tool is most commonly used to create quizzes or surveys but can also be used for managing assignments, collecting student feedback, writing book reviews, and collaborating on group projects. A useful feature of this tool is that it allows the collection of answers and provides basic analytical reviews of the obtained results. Then these results can be copied in another editor (Google Docs, Sheets) for further analysis.

- Google Sites- Google Site is a tool for creating websites and advantages of this tool is that the site created with Google Site is easily indexed in Google search. Also, forms and surveys can be added to the sites to collect needed data.

- Google Docs, Sheets, Slides- Google Docs is a tool that is very similar to Microsoft office and allows the use of basic text editors, spreadsheets and presentations. This tool is fully compatible with all tools in $\mathrm{G}$ suite for education.

Each of these cloud-based tools may be used individually but it is the joint use what makes the G Suite a unique and very useful set of tools. Google Suite for Education and "Google Universe" in general is a powerful group of integrated tools that it is worth to use.

Today's way of education requires the application of modern teaching methods enriched by the application of ICT, and this is especially expressed in higher education. In this way, all barriers for students are overcome, both in terms of geography, time and in terms of study costs. The tools that enable such a modern way of education are the $\mathrm{G}$ suite for education tools. Above all, it is important for every University to maintain a culture of using ICT in the teaching process if it wants to keep up with world trends. This will greatly contribute to 
attracting more and more foreign students because the application of e-learning overcomes all barriers. The pandemic crisis with the Covid 19 virus has further highlighted the importance of e-learning and the use of G-suite tools for the teaching process.

\section{EMPIRICAL RESEARCH OF THE PERCEPTIONS OF STUDENTS FOR BENEFITS AND CHALLENGES OF USING E-LEARNING TOOLS}

To explore student's perceptions of the benefits and challenges of using $\mathrm{G}$ suite for education tools, was used the method of representative sample and were used combined questions of different types. The data was obtained through an on-line questionnaire that contained closedended questions and also was used Likert scale for certain specific questions. The questionnaire was created with Google Forms and was sent via e-mail to the students of the Faculty of Economics in Prilep from all study years.130 students answered the questionnaire, which is an appropriate and representative sample on the basis of which relevant conclusions can be drawn. Due to the limited size of this paper, only the description of the obtained results will be made, and this will be the basis for further research through the use of appropriate quantitative analysis.

The first group of questions referred to the status of students who were covered by the questionnaire. Table 1 shows that are covered students from all study years equally, while regarding the department of study, most of them are in the department of Banking and finance and Accounting and audit, which corresponds to the structure of students enrolled in Faculty of economics in Prilep. The structure of students by departments is shown in Table 2.

Table 1. Year of study

\begin{tabular}{|l|l|}
\hline $\begin{array}{l}\text { Year of } \\
\text { study }\end{array}$ & Percent \\
\hline First year & $25.38 \%$ \\
\hline Second year & $23.85 \%$ \\
\hline Third year & $31.54 \%$ \\
\hline Fourth year & $19.23 \%$ \\
\hline
\end{tabular}

Table 2. Department of study

\begin{tabular}{|l|c|}
\hline Department & Percent \\
\hline Banking and finance & $31.54 \%$ \\
\hline E-business & $7.69 \%$ \\
\hline Marketing management & $12.31 \%$ \\
\hline International business & $1.54 \%$ \\
\hline Management & $3.85 \%$ \\
\hline Accounting and audit & $43.08 \%$ \\
\hline
\end{tabular}

Also, most of the students were female or $70 \%$ while male was $30 \%$ of the students.

Very interesting is the situation with the use of e-learning tools before the pandemic with the Covid 19 virus. This is exactly what the question is: Did you use any on-line learning tool before the pandemic with the Covid 19 virus? The majority of respondents, or $64.34 \%$, answered that they did not use any distance learning tools, while $35,66 \%$ answered yes to this question. This confirms the fact that before the pandemic, e-learning was very little used as a modern and contemporary concept in higher education. Even where such methods were used for the realization of the teaching process, they were usually the second and third cycle of studies. This is shown in Figure 1. 
Figure 1. Using of on-line learning tool before the pandemic with the Covid 19 virus

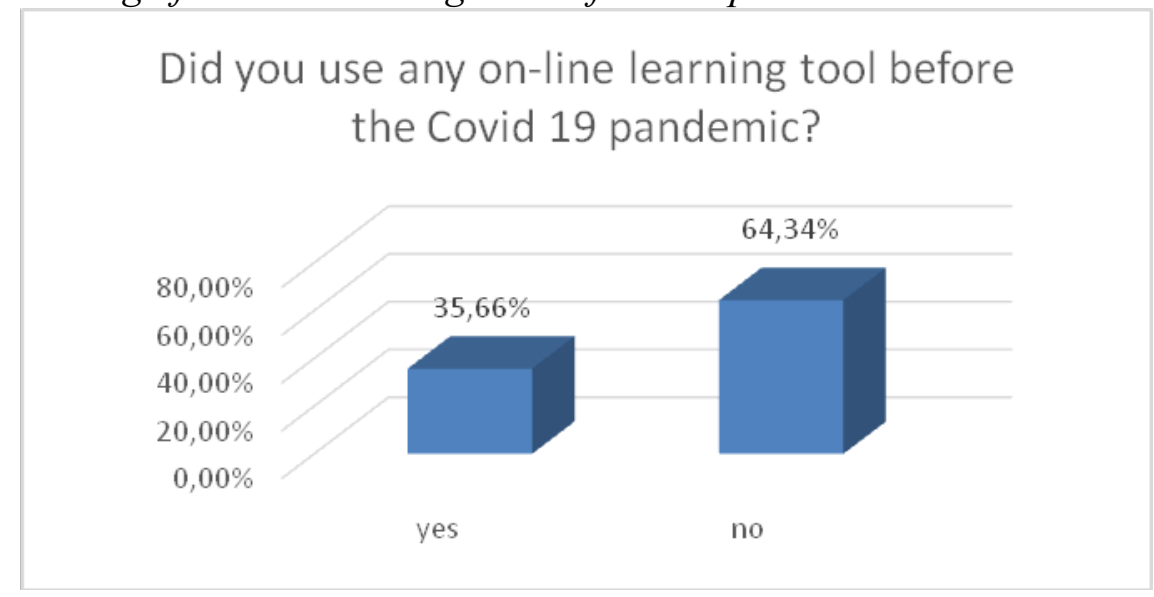

Universities should strive to make the most of the benefits that e-learning offers as a concept, as it has proven to be an effective tool for overcoming the barriers to the educational process. Especially in today's conditions, the pandemic with Covid 19 virus puts in the foreground all the advantages of e-learning that will be presented in this paper.

During the on-line teaching, professors and students were able to use a number of tools that are part of the Google cloud education platform, i.e. G Suite for education. The next question concerns which tools were most commonly used in teaching process by the professors and students at the Faculty of economics in Prilep. The results can be seen in Figure 2. Students may choose more answers to this question because more than one e-learning tool is used during the teaching process. In addition, these tools are fully compatible and are often used as a complement to each other. Almost all students used the Google classroom tool or $90.77 \%$, while many students also used Google Hangouts and Meet for online learning or $69.23 \%$. Respondents also frequently used G-mail for communication or $51.54 \%$ of respondents, while other tools from the $\mathrm{G}$ Suite platform were used relatively infrequently. Cloud tools that are less commonly used by students such as Google Drive, Google Forms, Google Docs and Sheets offer many opportunities. Using those opportunities would make the e-learning process easier.

Figure 2. Using of Google cloud tools during the on-line teaching

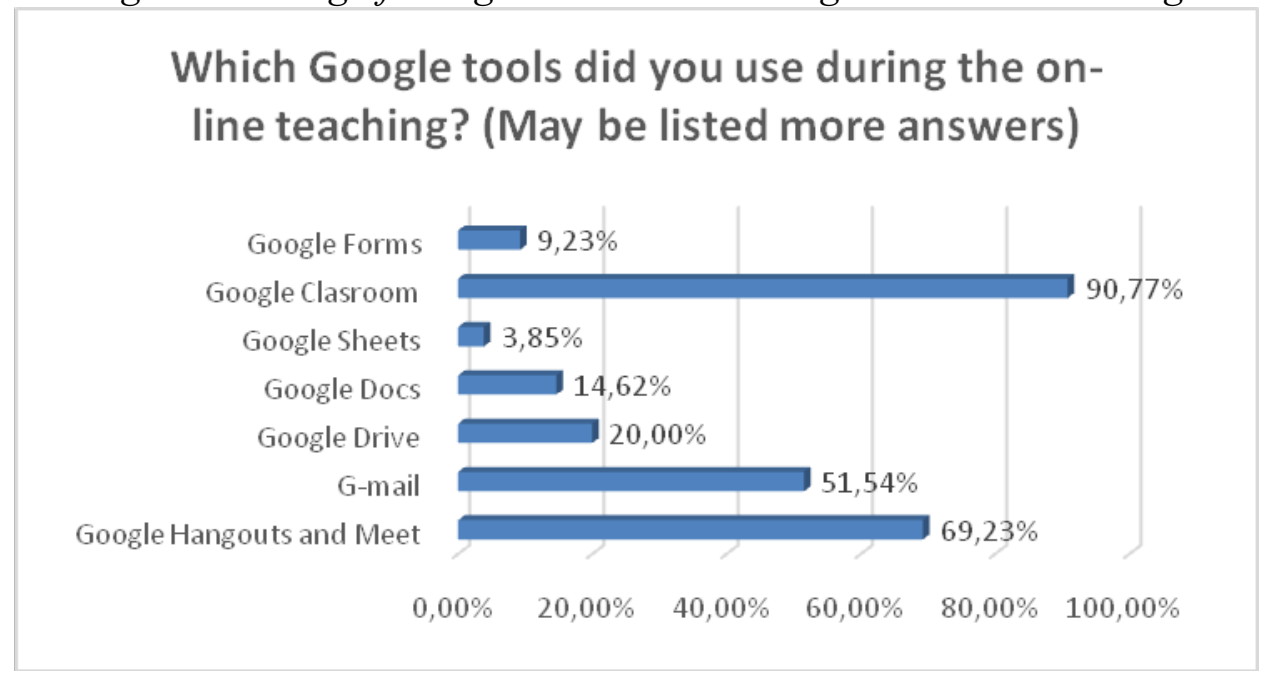

In this study, students were surveyed about the device they used to monitor online teaching. In addition, most of the students followed the lectures via laptop and smartphone. Also, this 
question was offered the opportunity to choose more than one answer, and it can be concluded that the same respondents used different devices when monitoring e-learning.

The next question in the survey is how much students are agreeing to maintain on-line teaching. The answers offered for this question were according to the Likert scale and according to the obtained results $21.9 \%$ of the respondents strongly agree, while $36.7 \%$ agree. Accordingly, $58.6 \%$ of respondents agree to follow this type of teaching, which is a relatively small percentage of world trends. Students are having some difficulty following online teaching, so the percentage of respondents who agree with this type of learning is relatively small. In the following analysis, we will return to why there is such a mood among students. Obtained results are presented on Figure 3.

Figure 3. Students agreeing for on-line teaching

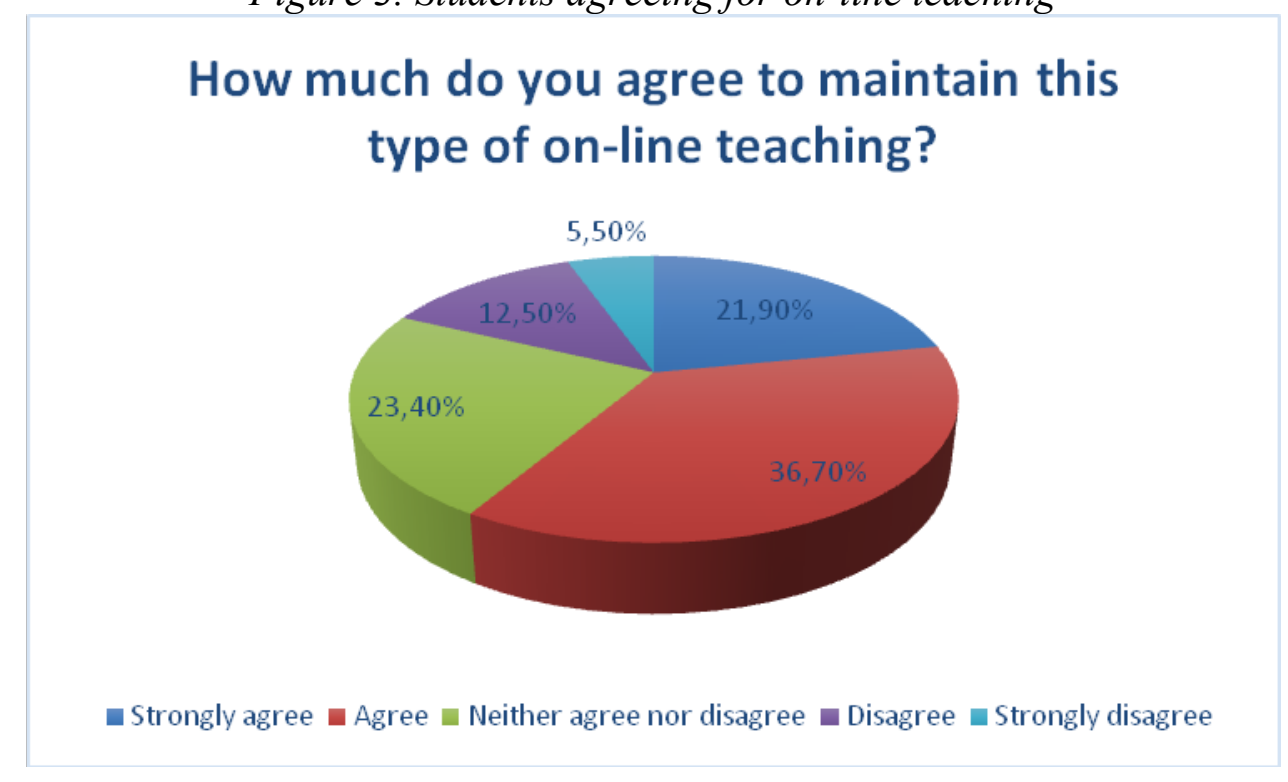

The most important part of this research concerns the student's perception of the benefits of using G Suit for education tools, but also the challenges that their users face. This is exactly what the next two questions in the survey are about.

Regarding the benefits in the survey this question were according to the Likert scale. Most respondents agree with the benefits of using the G Suite for education platform. The benefits of using these cloud tools were: the tools are easy and simple to use, interaction is possible between students and between students and professors, easy monitoring of events, easy access to the necessary learning materials, reduction of paper documents (papers, homework, quizzes), documents cannot be lost, facilitated on-line discussion, you are constantly informed, using these tools is free and save time. These results are shown on following figure. 
Figure 4. Benefits of e-learning tools

\section{How do you evaluate the benefits of $\mathrm{G}$ suite cloud based tools?}

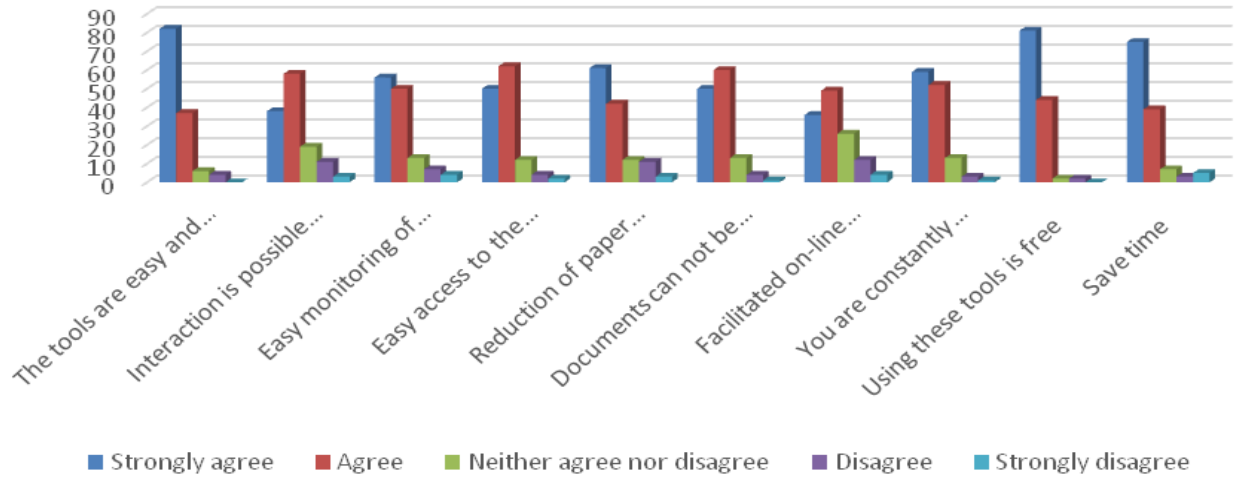

From the obtained results it can be seen that the respondents rank the benefits as the highest: the tools are easy and simple to use, using these tools is free and save time and after that are followed by the other benefits. However, the general conclusion is that students are satisfied with the use of $\mathrm{G}$ suit for education tools.

The next question concerns the problems and difficulties faced by users in the implementation of e-learning and the use of e-learning tools. From the analysis of the obtained answers we can conclude that the biggest problem of the students is not directly related to the use of $G$ suite for education tools but to the access to broadband Internet. This problem faced by the respondents is directly related to their mood for the realization of online teaching which was analyzed in Figure 3. In that part of the paper it was presented that only half or $58.6 \%$ of the respondents agree to attend online teaching, which is a relatively small percentage.

As other problems that the students faced when using the $G$ suite for education tools, that are problems primarily from the aspect of user registration $(11,61 \%)$, language barriers $(8,93 \%)$, upload and download of materials $(11,61 \%)$ etc. The results are shown in the figure 5 .

Figure 5. Challenges of using tools for on-line teaching

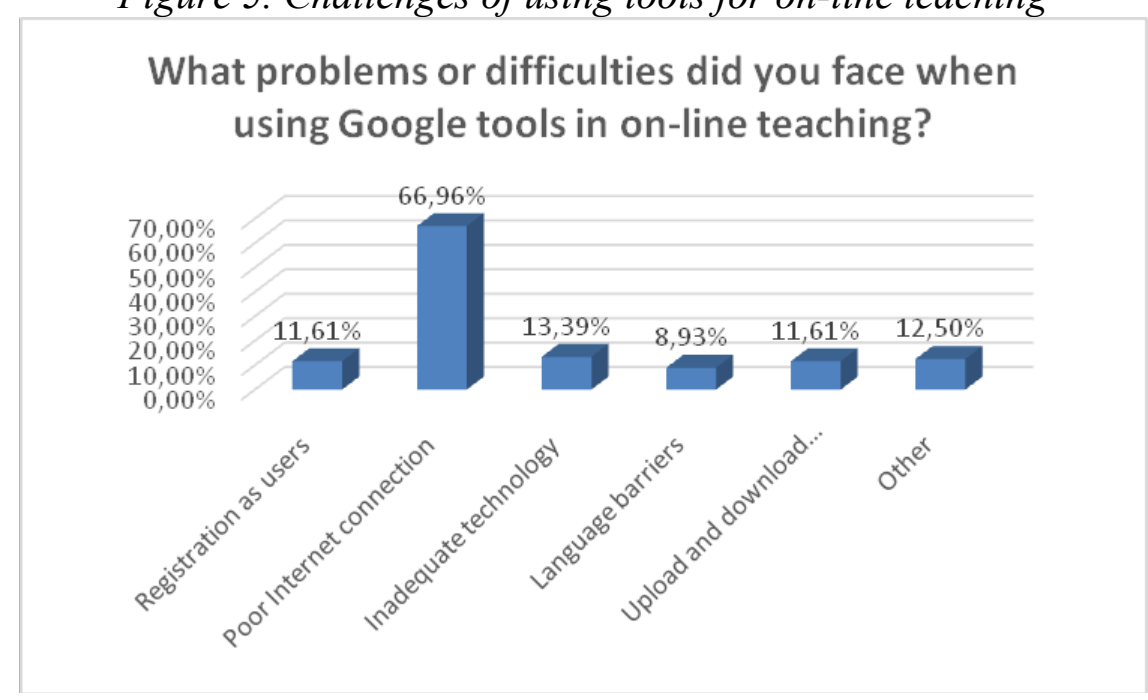

In this research, the results obtained in terms of preferences of the students for on-line teaching and conducting the exams in the future are especially interesting. First of all, when it 
comes to student preferences for online teaching, most respondents said they prefer a combined type of teaching (physical presence and online teaching) or $56.9 \%$ of them. The percentage of students who are interested for fully on-line teaching is very small or only $16.9 \%$, while $26.2 \%$ stated that they prefer classes only with physical presence. The results can be seen on the following figure.

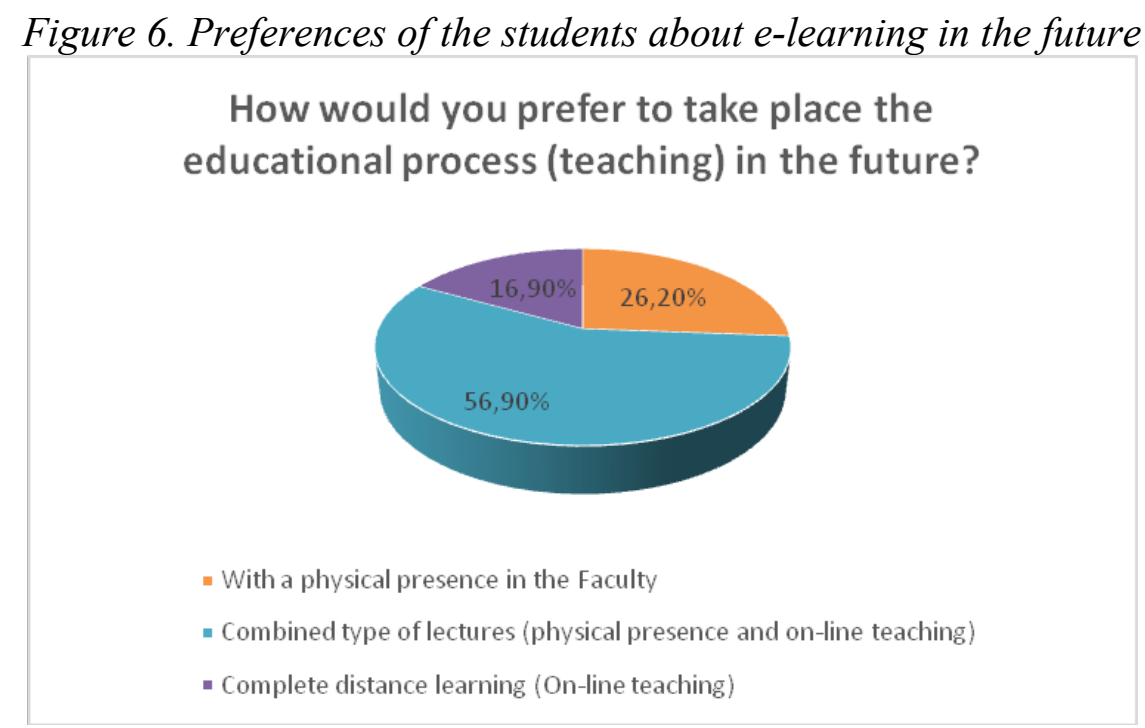

When it comes to on-line exams, most of the respondents stated that they want to take the exams with physical presence or $51.5 \%$ of them. The percentage of students who would like to take the full on-line exams is very small, or only $7.7 \%$ of them. A significant number of students, or $40.8 \%$, prefer to take the exams through a combination of physical exams and online exams. These results show that students still do not have confidence in taking exams through on-line tools, but they still prefer to take exams through the traditional way of physical presence. These results are presented in Figure 7.

Figure 7. Preferences of the students about on-line exam

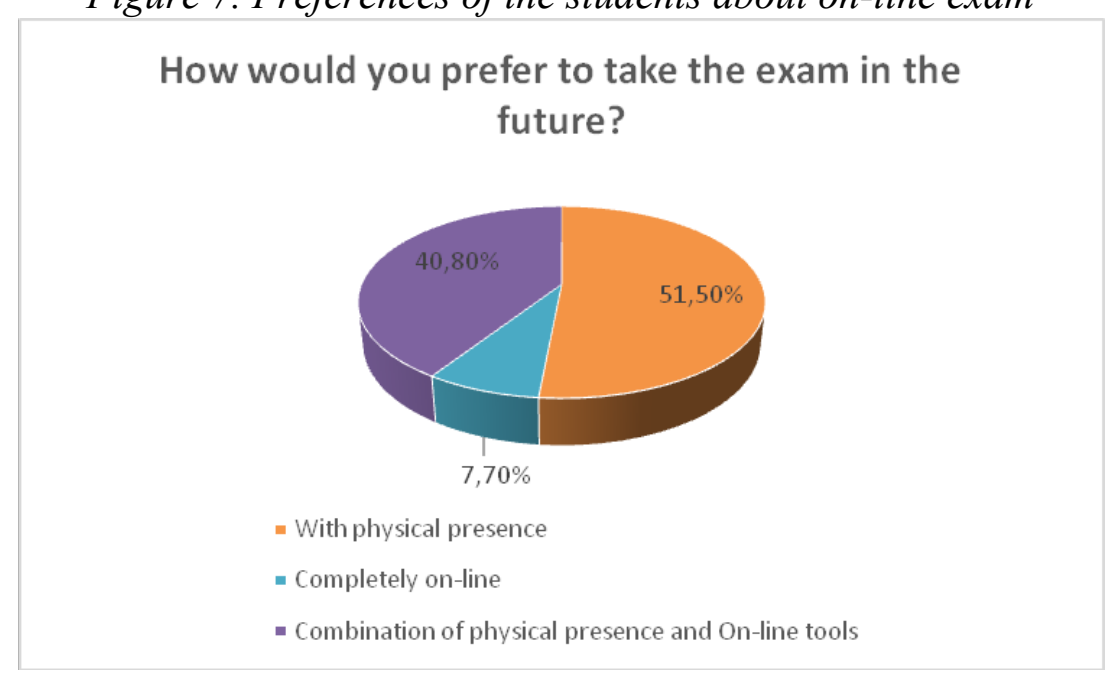

The data presented in terms of students' preferences for online teaching and take exam indicate the fact that most students prefer the realization of the teaching process and exams with physical presence or some combination of physical presence and on-line. These data 
would be a good basis for research into the reasons for these situations and students' preferences for the future teaching process and exam realization.

\section{CONCLUSION}

Distance learning is a flexible and open approach in the educational process and offers many ways of doing things both on the professor's side and on the student's side. That is why the skills acquired through e-learning methods are much more numerous, more diversified and more applicable in reality, even though they are acquired in a virtual environment.

On the other hand, the realization of the e-learning process requires certain preconditions such as technical infrastructure, broadband Internet, computer for everyone involved in the process, but also appropriate legislation. This global trend and phenomenon are also applied in the Universities of the Republic of North Macedonia, although still modestly and with relatively low intensity. The need for such modern ways of implementing the teaching process further emphasized the pandemic with the Covid 19 virus. As a result of that, Macedonian Universities have had to adapt to these changes. The Faculty of Economics in Prilep has realized the teaching process on all three cycles of studies through the on-line tools, i.e. through the $\mathrm{G}$ suite for education platform. This is cloud platform especially for education and united many tools that are completely compatible themselves.

The need of implementation of distance learning is why we decided to conduct this research in terms of student's perceptions of the use of cloud-based e-learning tools. This paper gives many answers above all: Are students satisfied with this type of teaching? Are students satisfied with the tools used for e-learning (G Suite for education)? What were the benefits to them of e-learning? What problems did they face with? Their thoughts on how to teach and take exams in the future?

As a general conclusion from this research, it can be said that students are satisfied with this way of teaching, although some of them are still skeptical about the full on-line teaching process. Their skepticism probably stems from the problems they encountered during elearning. According to the results, the biggest problem for students was the poor Internet connection, which is unacceptable in the 21 st century. On the other hand, most students positively evaluate the benefits of using G Suite for education tools. Also, when analyzing the results obtained, it can be concluded that the benefits of using these tools are far greater than the problems faced by students. Regarding the problems when using the G Suite tools, those problems are insignificant and only a part of the students have faced them (user registration, language barriers, upload and download of materials).

Also, very interesting are the results of the research regarding the preferences of students for teaching and taking exams in the future. From these results it can be concluded that a very small part of the students prefers full on-line teaching, and an even smaller number of students prefer full on-line taking of exams. It means that it's necessary a lot of work to establish full on-line process for education, especially regarding the trust of students on this new modern way of teaching.

The results of this research can be the basis for further deeper analysis of all aspects of elearning. 


\section{REFERENCES}

B. Briggs, E. Kassner, Enterprise cloud strategy-Second edition, Microsoft Press, Washington USA, 2017

E. Simmon, Evaluation of cloud computing Services based on NIST SP 800-145, National Institute of standards and technology, U.S Department of commerce, USA, 2018

ELSA (The European Law Student's Association) ((2017/2018), "G Suite Guidelines", available at https://files.elsa.org/Guidelines_G_ELSA.pdf (accessed 09 july 2020).

Garrison D. R., and Anderson T.( 2003), "E-Learning in the 21st Century", London: Routledge /Falmer.

J. El-Zein, S. Viswanathan, Cloud management for dummies, John Wiley and Sons, USA, 2016

Hanafizadeh P. and all. (2008), "E-Readiness assessment model of universities and higher education institutions" Journal of Research and Planning in Higher Education, 3. http://www.informit.com.au/ijebm.html, Canada, 2010, 48-60

K. Chandrasekaran, Essentials of cloud computing, CRC Press Taylor \& Francis Group, Boca Raton, USA, 2015

Kenneth J. Brown (2005), "A Field Study of Employee e-Learning Activity and Outcomes", Human Resource Development Quarterly, vol. 16, no. 4, Winter 2005, Wiley Periodicals, Inc., Iowa, 465-476

L. C. Miller, IaaS for dummies, Oracle special edition, John Wiley and Sons, USA, 2017

Means B. and Olson K. (1995), "Technology's Role In Education Reform", Office of Educational Research and Improvement, U.S. Department of Education, Washington, available at: https://www2.ed.gov/PDFDocs/techrole.pdf (accessed 05 july 2020).

M. Smith, Cloud Strategy Leadership, Gartner Inc, 2017

Mousavi S., and all. (2016), "Assess the readiness of e-learning in the students of Zanjan University of Medical Sciences", Journal of Medical Education Development,8(20).

Nerguizian V. and all.(2011), "Active e-Learning Approach for e-Business", International Journal of e-Business Management, vol. 5, no. 1, DOI 10.3316/IJEBM0501048, C RMIT Publishing, available at: https://www.academia.edu/21471672/Active_eLearning_Approach for e-business (accessed 05 july 2020).

Ouadoud M. and all. (2016), "Studying and comparing the free e-learning platforms", 4th IEEE International Colloquium on Information Science and Technology (CIST), Tangier, Morocco, available at: file:///C:/Users/Acer/Downloads/ouadoud20161.pdf (accessed 05 july 2020).

Ramboll Management (2005), "The use of ICT for learning and teaching in initial vocational education and training", Final Report to the EU Commission Brussels: DG Education and Culture.

R. Hill, L. Hirsh, P. Lake, S. Moshiri, Guide to cloud computing-Principles and practice, Springer-Verlag, London, 2013

S. Bhowmik, Cloud computing, Cambridge University Press, United Kingdom, 2017

The Zapier Team (2017), "The Ultimate Guide to G Suite: Everything you need to set up and administer Google's apps for your business", LeanPub. available at: https://cdn.zapier.com/storage/learn_ebooks/66c3a6e092e0ee3771050331df69cbda.pdf (ac cessed 04 july 2020).

Titrade C. and all.(2009), "E-Learning", Annals of the University of Oradea, Economic Science Series, University of Oradea, Romania, 1066-1069 
Usun S, (2005), “A Model Proposal For Instructional Technology and Multimedia" Center for Faculty of Education, The Turkish Online Journal of Educational Technology - TOJET, October 2005 ISSN: 1303-6521 volume 4 Issue 4 Article 2

Wahab A. (2020), "Online and Remote Learning in Higher Education Institutes: A Necessity in light of COVID-19 Pandemic", Higher Education Studies; Vol. 10, No. 3; 2020 ISSN 1925-4741 E-ISSN 1925-475X Published by Canadian Center of Science and Education, available at file:///C:/Users/Acer/Downloads/OnlineandRemoteLearning.pdf (accessed 06 july 2020).

World Bank (2020), "Rapid Response Briefing Note: Remote Learning and COVID-19" Outbreak (English). Washington, DC: World Bank Group.

Zivanovic R. and all. (2010), "Use of Computers and Internet in The Educational System of The Republic of Macedonia", Foundation Open Society Institute - Macedonia and Metamorphosis Foundation Skopje, Macedonia, available at: https://metamorphosis.org.mk/wp-content/uploads/2014/10/upotreba-na-kompjuterite-voobrazovanieto.pdf (accessed 04 july 2020).

https://shakeuplearning.com/blog/g-suite-education-need-know/ (accessed 09 july 2020). http://services.google.com/fh/files/newsletters/distance learning_strategies for education_le aders march 2020.pdf (accessed 09 july 2020).

https://www.commonsense.org/education/articles/teachers-essential-guide-to-googleclassroom (accessed 09 july 2020).

https://hwb.gov.wales/support-centre/hwb-services/g-suite-for-education (accessed 09 july 2020).

https://www.kenet.or.ke/sites/default/files/understanding_google_apps_for_education_0.pdf 